
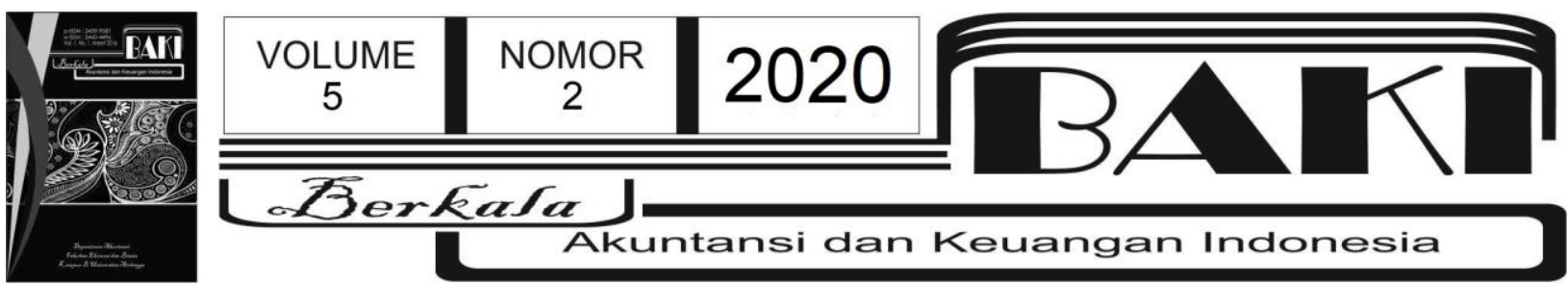

\title{
Analisis Faktor-Faktor yang Mempengaruhi Kebijakan Hutang
}

\author{
Suci Meta Saputri ${ }^{1,2}$, Widi Hariyanti ${ }^{1}$, Yunus Harjito ${ }^{1}$ \\ ${ }^{1}$ Universitas Setia Budi \\ 2suci.meta10@gmail.com
}

INFOARTIKEL ABSTRACT

Histori Artikel:

Tanggal Masuk 21 Maret 2020

Tanggal Diterima 10 Agustus

2020

Tersedia Online 30 September 2020

\section{Keywords: \\ Profitability, Liquidity, Asset \\ Structure, Company Growth, Debt Policy}

Kata Kunci:

Profitabilitas; Likuiditas;

Struktur Aset; Pertumbuhan Perusahaan; Kebijakan Hutang

\begin{abstract}
This study aims to analyze the effect of profitability, liquidity, asset structure and company growth on debt policy. The sample in this study amounted to 490 samples obtained from 98 companies for 5 years with purposive sampling method. The data analysis technique used in this research is panel data regression analysis technique which is processed using Eviews 9 software. The results show that profitability and liquidity have a negative effect on debt policy, while asset structure has no effect on debt policy, and company growth has a positive effect on debt policy. debt policy.
\end{abstract}

\section{A B STRAK}

Penelitian ini bertujuan untuk menganalisis pengaruh profitabilitas, likuiditas, struktur aset, dan pertumbuhan perusahaan terhadap kebijakan hutang. Sampel dalam penelitian ini berjumlah 490 sampel yang diperoleh dari 98 perusahaan selama 5 tahun dengan metode purposive sampling. Teknik analisis data yang digunakan dalam penelitian ini adalah teknik analisis regresi data panel yang diolah dengan menggunakan software eviews 9. Hasil penelitian menunjukkan bahwa profitabilitas dan likuiditas berpengaruh negatif terhadap kebijakan hutang, sedangkan struktur aset tidak berpengaruh terhadap kebijakan hutang, dan pertumbuhan perusahaan berpengaruh positif terhadap kebijakan hutang. 


\section{Pendahuluan}

Perusahaan dalam menjalankan kegiatan operasionalnya memerlukan dana. Sumber dana dapat berasal dari dalam perusahaan (intern) misalnya laba ditahan dan dana aliran kas. Sedangkan sumber dana yang berasal dari luar perusahaan (extern) seperti penerbitan saham baru dan hutang. Keputusan untuk memilih sumber dana merupakan hal penting bagi perusahaan karena akan berpengaruh terhadap keberlangsungan hidup perusahaan. Sapitri (2018) menyatakan bahwa kebijakan hutang timbul karena pengambilan keputusan oleh pengelola perusahaan yang disebabkan kurangnya dana internal dalam memenuhi dan mengembangkan kebutuhan perusahaan. Keputusan akan penggunaan hutang mengharuskan perusahaan menyeimbangkan tingkat ekspektasi pengembalian yang relatif lebih tinggi dengan resiko yang meningkat (Brigham dan Houston, 2011). Terdapat perusahaan yang dinyatakan pailit karena tidak dapat memenuhi seluruh kewajibannya. Sebagai contoh yaitu perusahaan yang bergerak di industri sub sektor pulp dan kertas, PT Dwi Aneka Jaya Kemasindo Tbk (DAJK) telah dinyatakan pailit oleh Pengadilan Niaga Jakarta Pusat pada tanggal 22 November 2017. DAJK tersebut dinyatakan pailit akibat tidak dapat membayar hutangnya sebesar Rp 1,15 triliun (Utami, 2018).

Terdapat hasil yang tidak konsisten dari penelitian terdahulu yang berkaitan dengan kebijakan hutang. Berdasarkan hasil penelitian yang dilakukan oleh Hardiningsih dan Oktaviani (2012) menyatakan bahwa profitabilitas berpengaruh positif terhadap kebijakan hutang. Berbeda dengan hasil penelitian yang dilakukan oleh Ehikioya (2018), Rosa (2016), Yuana dkk. (2018), Desmintari dan Yetty (2016), dan Trisnawati (2016) yang menyatakan bahwa profitabilitas berpengaruh negatif terhadap kebijakan hutang. Sedangkan penelitian yang dilakukan oleh Ramadhani dan Barus (2018) menyatakan bahwa profitabilitas tidak berpengaruh terhadap kebijakan hutang. Berdasarkan hasil penelitian yang dilakukan oleh Primantara dan Dewi (2016) serta Akoto dan Vitor (2014) menyatakan bahwa likuiditas berpengaruh positif terhadap kebijakan hutang. Berbeda dengan hasil penelitian yang dilakukan oleh Ramadhani dan Barus (2018), Yuana dkk. (2018), Desmintari dan Yetty (2016), Cortez dan Susanto (2012), dan Susanti (2014) menyatakan bahwa likuiditas berpengaruh negatif terhadap kebijakan hutang.

Penelitian ini menggunakan analisis regresi data panel yang diolah dengan software eviews. Alasan menggunakan analisis regresi data panel dikarenakan data pada penelitian ini merupakan data panel atau gabungan dari data time series dan cross section. Penelitian ini dilakukan selama 5 tahun agar mendapatkan hasil yang lebih mencerminkan keadaan yang sebenarnya. Penelitian ini dilakukan karena terdapat ketidakkonsistenan hasil penelitian terdahulu. Hasil penelitian yang dilakukan oleh Putra dan Ramadhani (2017), Trisnawati (2016), Akoto dan Vitor (2014), serta Hardiningsih dan Oktaviani (2012) menyatakan bahwa struktur 
aset berpengaruh positif terhadap kebijakan hutang. Berbeda dengan hasil penelitian yang dilakukan oleh Linda dkk. (2017) dan Indraswary dkk. (2016) yang menyatakan bahwa struktur aset berpengaruh negatif terhadap kebijakan hutang. Sedangkan penelitian yang dilakukan oleh Prayogi dkk. (2016), Desmintari dan Yetty (2016), dan Rifai (2015) menyatakan bahwa struktur aset tidak berpengaruh terhadap kebijakan hutang. Berdasarkan hasil penelitian yang dilakukan oleh Putra dan Ramadhani (2017), Trisnawati (2016), dan Sinaga (2017) menyatakan bahwa pertumbuhan perusahaan berpengaruh positif terhadap kebijakan hutang. Berbeda dengan hasil penelitian yang dilakukan oleh Prayogi dkk. (2016), Suryani (2015), dan Rifai (2015) yang menyatakan bahwa pertumbuhan perusahaan tidak berpengaruh terhadap kebijakan hutang. Berdasarkan uraian pada latar belakang di atas, maka pertanyaan penelitiannya adalah:

1. Apakah profitabilitas berpengaruh terhadap kebijakan hutang?

2. Apakah likuiditas berpengaruh terhadap kebijakan hutang?

3. Apakah struktur aset berpengaruh terhadap kebijakan hutang?

4. Apakah pertumbuhan perusahaan berpengaruh terhadap kebijakan hutang?

\section{Tinjauan Pustaka}

\subsection{Pecking Order Theory}

Pecking Order Theory menetapkan suatu urutan keputusan pendanaan dimana manajer pertama memilih menggunakan laba ditahan, utang dan penerbitan saham sebagai pilihan terakhir (Suryani, 2015). Menurut Husnan (2012), Pecking order theory menjelaskan mengapa perusahaan-perusahaan yang profitable umumnya memiliki hutang dalam jumlah yang sedikit. Bukan berarti perusahaan mempunyai target debt ratio yang kecil tetapi karena perusahaan hanya membutuhkan sedikit dana dari eksternal. Terdapat dua alasan mengapa perusahaan yang kurang profitable akan cenderung mempunyai hutang yang lebih besar, yaitu karena sumber pendanaan internal yang tidak cukup dan sumber pendanaan eksternal yang lebih disukai adalah hutang.

\subsection{Trade Off Theory}

Trade Off Theory merupakan teori struktur modal yang menyatakan bahwa perusahaan menukar manfaat pajak dari pendanaan hutang dengan permasalahan yang ditimbulkan oleh potensi kebangkrutan (Brigham dan Houston, 2011). Menurut teori trade off, perusahaan dengan aset yang berwujud dan aman serta penghasilan kena pajak yang besar seharusnya beroperasi pada tingkat utang yang tinggi (Andina, 2013). 


\subsection{Hipotesis Penelitian}

\subsubsection{Pengaruh Profitabilitas Terhadap Kebijakan Hutang}

Profitabilitas merupakan kemampuan perusahan untuk mendapatkan laba dalam suatu periode tertentu (Sinaga, 2017). Profitabilitas mempengaruhi kebijakan hutang karena ketika kondisi profitabilitas tinggi perusahaan cenderung mengandalkan sumber dana internal dan sebaliknya pada kondisi profitabilitas rendah perusahaan akan mengandalkan sumber dana eksternal (Surya dan Rahayuningsih, 2012). Sesuai dengan Pecking Order Theory yang menetapkan suatu urutan keputusan pendanaan dimana perusahaan memakai laba ditahan sebagai pilihan pertama, kemudian hutang sebagai pilihan kedua, dan penerbitan saham sebagai opsi yang terakhir. Menurut Sinaga (2017) semakin tinggi laba yang diperoleh perusahaan maka akan semakin kecil penggunaan hutang dalam pendanaan perusahaan karena perusahaan dapat menggunakan internal equity yang diperoleh dari laba ditahan terlebih dahulu. Apabila kebutuhan dana belum tercukupi, perusahaan dapat menggunakan hutang. Hasil penelitian yang dilakukan oleh Ehikioya (2018), Rosa (2016), Yuana dkk. (2018), Desmintari dan Yetty (2016), dan Trisnawati (2016) yang menyatakan bahwa profitabilitas berpengaruh negatif terhadap kebijakan hutang. Berdasarkan uraian tersebut dapat dirumuskan hipotesis:

$\mathrm{H}_{1}$ : Profitabilitas berpengaruh negatif terhadap kebijakan hutang.

\subsubsection{Pengaruh Likuiditas Terhadap Kebijakan Hutang}

Brigham dan Houston (2013) menjelaskan bahwa likuiditas adalah kemampuan suatu perusahaan untuk melunasi hutangnya ketika hutang tersebut jatuh tempo di tahun berikutnya. Perusahaan dengan tingkat likuiditas yang tinggi cenderung memiliki tingkat hutang yang rendah (Sapitri, 2018). Sesuai dengan pecking order theory yang menetapkan suatu urutan keputusan pendanaan dimana perusahaan pertama kali akan memilih menggunakan laba ditahan, pilihan yang kedua adalah hutang dan penerbitan saham sebagai pilihan terakhir. Berdasarkan hasil penelitian yang dilakukan oleh Ramadhani dan Barus (2018), Yuana dkk. (2018), Desmintari dan Yetty (2016), Cortez dan Susanto (2012), dan Susanti (2014) menyatakan bahwa likuiditas berpengaruh negatif terhadap kebijakan hutang. Berdasarkan uraian tersebut dapat dirumuskan hipotesis:

$\mathrm{H}_{2}$ : Likuiditas berpengaruh negatif terhadap kebijakan hutang.

\subsubsection{Pengaruh Struktur Aset Terhadap Kebijakan Hutang}


Struktur aset adalah komposisi jumlah aset tetap yang dimiliki perusahaan (Yeniatie dan Destriana, 2010). Perusahaan yang mempunyai aset tetap yang lebih besar (berusia panjang), apalagi jika digabungkan dengan tingkat permintaan produk yang stabil, akan menggunakan hutang yang lebih besar (Hanafi dan Halim, 2012). Teori trade off menyatakan bahwa semakin banyak struktur aset suatu perusahaan berarti semakin banyak aset yang dijadikan jaminan untuk mendapatkan sumber dana eksternal berupa hutang. Hasil penelitian yang dilakukan oleh Putra dan Ramadhani (2017), Trisnawati (2016), Akoto dan Vitor (2014), serta Hardiningsih dan Oktaviani (2012) menyatakan bahwa struktur aset berpengaruh positif terhadap kebijakan hutang. Berdasarkan uraian tersebut dapat dirumuskan hipotesis:

$\mathrm{H}_{3}$ : Struktur aset berpengaruh positif terhadap kebijakan hutang.

\subsubsection{Pengaruh Pertumbuhan Perusahaan Terhadap Kebijakan Hutang}

Pertumbuhan perusahaan menunjukan bahwa perusahaan tersebut sedang melakukan perluasan usaha sehingga dapat dipastikan perusahaan tersebut membutuhkan dana untuk mendukung perluasan usahanya tersebut (Surya dan Rahayuningsih, 2012). Yeniatie dan Destriana (2010) menjelaskan pertumbuhan perusahaan yang besar mempunyai pengaruh positif terhadap hutang perusahaan, karena suatu perusahaan yang sedang berada pada tahap pertumbuhan akan membutuhkan dana yang besar untuk melakukan ekspansi. Semakin besar pertumbuhan perusahaan akan semakin besar dana yang dibutuhkan dan semakin besar pula hutang yang digunakan (Andina, 2013). Sesuai dengan pecking order theory, dimana perusahaan akan memilih pendanaan internal terlebih dahulu kemudian hutang dan saham sebagai pilihan terakhir. Berdasarkan hasil penelitian yang dilakukan oleh Putra dan Ramadhani (2017), Trisnawati (2016), dan Sinaga (2017) menyatakan bahwa pertumbuhan perusahaan berpengaruh positif terhadap kebijakan hutang. Berdasarkan uraian tersebut dapat dirumuskan hipotesis:

$\mathrm{H}_{4}$ : Pertumbuhan perusahaan berpengaruh positif terhadap kebijakan hutang.

\section{Metodologi Penelitian}

\subsection{Jenis Penelitian}

Jenis penelitian ini merupakan penelitian kuantitatif. Pada penelitian ini data yang digunakan adalah data sekunder dalam bentuk laporan keuangan tahunan perusahaan manufaktur yang terdaftar di BEI periode 2014-2018. Data tersebut diperoleh dari website www.idx.co.id dan diolah dengan regresi data panel menggunakan software eviews 9. 


\subsection{Sampel}

Dalam penelitian ini teknik penarikan sampel yang digunakan yaitu purposive sampling dengan kriteria sebagai berikut:

1. Perusahaan manufaktur yang terdaftar di Bursa Efek Indonesia dan mempublikasikan laporan keuangan tahunan secara lengkap selama periode penelitian tahun 2014-2018.

2. Menyediakan semua data yang dibutuhkan dalam perhitungan variabel-variabel pada penelitian ini.

3. Perusahaan manufaktur yang menggunakan mata uang rupiah dalam laporan tahunannya.

4. Perusahaan yang Debt to Equity Rationya positif.

\subsection{Operasional Variabel}

\subsubsection{Kebijakan Hutang}

Kebijakan hutang dalam penelitian ini diukur menggunakan rasio Debt to Equity Ratio (DER). Perhitungan DER menggunakan rumua (Ehikioya, 2018):

$$
D E R=\frac{\text { Total Hutang }}{\text { Total Ekuitas }}
$$

\subsubsection{Profitabilitas}

Profitabilitas dalam penelitian ini diukur dengan rasio Return On Asset (ROA). Perhitungan ROA menggunakan rumus (Desmintari dan Yetty, 2016):

$$
R O A=\frac{\text { Earning After Tax }}{\text { Total Assets }}
$$

\subsubsection{Likuiditas}

Rasio likuiditas yang digunakan pada penelitian ini adalah rasio lancar (current ratio). Perhitungan current ratio menggunakan rumus (Akoto dan Vitor, 2014):

$$
\text { CurrentRaio }=\frac{\text { Aset Lancar }}{\text { Hutang Lancar }}
$$




\subsubsection{Struktur Aset}

Perhitungan struktur aset dalam penelitian ini menggunakan rumus (Cortez dan Susanto, 2012):

$$
\text { Struktur Aset }=\frac{\text { Total Aset Tetap }}{\text { Total Aset }}
$$

\subsubsection{Pertumbuhan Perusahaan}

Rumus perhitungan pertumbuhan perusahaan dalam penelitian ini yaitu (Chandrasekharan, 2012):

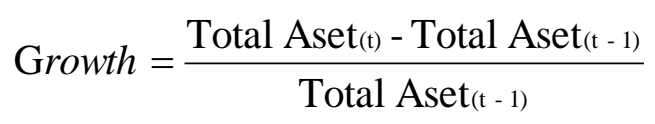

\section{Analisis dan Pembahasan}

\subsection{Deskripsi Sampel}

Populasi dalam penelitian ini adalah perusahaan manufaktur yang terdaftar di Bursa Efek Indonesia pada tahun 2014-2018, dengan jumlah populasi 166 perusahaan. Pemilihan sampel dilakukan dengan menggunakan metode purposive sampling. Proses pemilihan sampel tersebut tampak pada tabel 4.1. sebagai berikut:

\begin{tabular}{|c|c|c|}
\hline No & Kriteria & Jumlah \\
\hline 1. & $\begin{array}{l}\text { Perusahaan manufaktur yang terdaftar di Bursa Efek Indonesia (BEI) dan } \\
\text { mempublikasikan laporan keuangan tahunan secara lengkap selama periode } \\
\text { penelitian tahun 2014-2018. }\end{array}$ & 129 \\
\hline 2. & $\begin{array}{l}\text { Menyediakan semua data yang dibutuhkan dalam perhitungan variabel- } \\
\text { variabel pada penelitian ini. }\end{array}$ & 129 \\
\hline 3. & $\begin{array}{l}\text { Perusahaan manufaktur yang menggunakan mata uang rupiah dalam laporan } \\
\text { tahunannya. }\end{array}$ & 104 \\
\hline 4. & Perusahaan yang Debt to Equity Rationya positif & 98 \\
\hline \multicolumn{2}{|c|}{ Jumlah Perusahaan Sampel } & 98 \\
\hline \multicolumn{2}{|c|}{ Tahun Pengamatan } & 5 \\
\hline \multicolumn{2}{|r|}{ Total Data Selama Tahun Pengamatan (5 Tahun x 98 Perusahaan) } & 490 \\
\hline
\end{tabular}

Tabel 4.1. Hasil Kriteria Sampel 


\subsection{Hasil Statistik Deskriptif}

Analisis statistik deskriptif berfungsi memberikan gambaran data yang dilihat dari nilai rata-rata (mean), nilai tertinggi (maximum), nilai terendah (minimum), dan standar deviasi. Hasil analisis statistik deskriptif disajikan pada tabel berikut:

Tabel 4.2. Hasil Statistik Deskriptif

\begin{tabular}{lccccr} 
& DER & ROA & CR & SA & GROWTH \\
Mean & 1,252245 & 0,056181 & 2,313214 & 0,388487 & 0,112857 \\
Maximum & 11,09793 & 0,920997 & 12,99460 & 0,966617 & 6,218770 \\
Minimum & 0,040291 & $-0,391844$ & 0,052584 & 0,016615 & $-0,854541$ \\
Std. Dev. & 1,477030 & 0,103305 & 1,835178 & 0,189545 & 0,333011 \\
\hline
\end{tabular}

Sumber: Data sekunder yang telah diolah

\subsection{Pemilihan Model Regresi}

Pemilihan model regresi data panel dilakukan dengan menggunakan uji chow dan uji hausman. Pengujian ini bertujuan untuk memilih model estimasi yang sesuai dengan penelitian ini. Model regresi data panel terdiri dari common effect, fixed effect, dan random effect.

\subsubsection{Uji Chow}

Uji chow bertujuan untuk memilih model mana yang lebih baik digunakan antara common effect model atau fixed effect model. Berikut ini disajikan hasil Uji Chow untuk menunjukkan pemilihan model regresi penelitian:

\begin{tabular}{lccc}
\multicolumn{1}{c}{ Tabel 4.3. Hasil Uji Chow } & & \\
Erocts Test & Statistic & d.f. & Prob. \\
Cross-section F & 9,341591 & $(97.388)$ & 0,0000 \\
Cross-section Chi-square & 590,250054 & 97 & 0,0000 \\
\hline
\end{tabular}

Sumber: Data sekunder yang telah diolah

Nilai probabilitas cross-section $\mathrm{F}$ sebesar 0,0000 yang berarti lebih kecil dari taraf signifikansi 0,05 . Apabila nilai probabilitas untuk cross-section $\mathrm{F}$ kurang dari nilai signifikansinya yaitu 0,05 maka model yang dipilih adalah fixed effect. Sebaliknya jika nilainya lebih dari 0,05 maka model yang dipilih adalah common effect. Berdasarkan uji chow diatas maka model estimasi yang dipilih adalah fixed effect model. 


\subsubsection{Uji Hausman}

Hasil yang diperoleh dari uji chow adalah fixed effect model, maka langkah selanjutnya adalah melakukan uji hausman. Uji hausman dilakukan untuk memilih model mana yang lebih baik digunakan antara fixed effect atau random effect. Berikut ini disajikan tabel uji hausman:

Tabel 4.4. Hasil Uji Hausman

\begin{tabular}{cccc} 
Test Summary & Chi-Sq. Statistic & Chi-Sq. d.f. & Prob. \\
Cross-section random & 9,812761 & 4 & 0,0437 \\
\hline
\end{tabular}

Sumber: Data sekunder yang telah diolah

Nilai prob. Cross-section random sebesar 0,0437 dimana nilai tersebut lebih kecil dari taraf signifikansi 0,05 sehingga model estimasi yang tepat adalah fixed effect. Berdasarkan uji chow dan uji hausman yang telah dilakukan sebelumnya, maka model regresi data panel yang tepat digunakan untuk penelitian ini adalah fixed effect model.

\subsection{Hasil Analisis Regresi Data Panel}

Dari pengujian model estimasi yang telah dilakukan sebelumnya, maka model regresi yang sesuai untuk penelitian ini adalah fixed effect model. Berikut ini adalah hasil regresi data panel menggunakan model fixed effect:

Tabel 4.5. Hasil Regresi Model Fixed Effect

\begin{tabular}{lccc}
\multicolumn{1}{c}{ Variable } & Coefficient & t-Statistic & Prob. \\
C & 1,888231 & 5,830672 & $0,0000^{* * *}$ \\
ROA & $-2,801539$ & $-4,270523$ & $0,0000^{* * *}$ \\
CR & $-0,143965$ & $-3,373509$ & $0,0008^{* * *}$ \\
SA & $-0,562838$ & $-0,829485$ & 0,4073 \\
GROWTH & 0,647567 & 5,157702 & $0,0000^{* * *}$ \\
\hline R-square & & & 0,777308 \\
Adjusted R-square & & & 0,719340 \\
F-statistic & & 13,40911 \\
Prob(F-statistic) & & & 0,000000 \\
\hline
\end{tabular}

Sumber: Data sekunder yang telah diolah

Keterangan: ${ }^{*}=$ Signifikan pada level $10 \% ;{ }^{* *}=$ Signifikan pada level $5 \% ;{ }^{* * *}=$ Signifikan pada level $1 \%$.

Berdasarkan hasil analisis pada tabel 4.5. diperoleh hasil persamaan regresi data panel sebagai berikut:

$\mathrm{DER}=1,888231-2,801539 \mathrm{ROA}-0,143965 \mathrm{CR}-0,562838 \mathrm{SA}+0,647567 \mathrm{GROWTH}+\mathrm{e}$

Berdasarkan hasil uji hipotesis dapat diketahui bahwa profitabilitas dan likuiditas berpengaruh negatif signifikan terhadap kebijakan hutang. Struktur aset tidak berpengaruh terhadap 
kebijakan hutang. Sedangkan pertumbuhan perusahaan berpengaruh positif signifikan terhadap kebijakan hutang.

\subsection{Pembahasan Hasil Penelitian}

\subsubsection{Pengaruh Profitabilitas terhadap Kebijakan Hutang}

Hasil pengujian menunjukkan bahwa variabel profitabilitas yang diproksikan dengan return on assets (ROA) mempunyai nilai koefisien sebesar -2,801539 dengan nilai signifikansi sebesar 0,0000. Nilai sign probabilitas dari profitabilitas lebih kecil dari 0,01 atau signifikan pada level $1 \%$ maka profitabilitas berpengaruh negatif signifikan terhadap kebijakan hutang. Dengan demikian, hipotesis yang telah dirumuskan $(\mathrm{H} 1)$ diterima. Nilai koefisien profitabilitas yang negatif menunjukkan bahwa semakin tinggi profitabilitas maka akan semakin kecil hutang perusahaan karena perusahaan dapat menggunakan internal equity terlebih dahulu. Hal ini sesuai dengan pecking order theory yang menetapkan suatu urutan keputusan pendanaan dimana perusahaan pertama kali akan memilih untuk menggunakan laba ditahan, hutang, dan penerbitan saham sebagai pilihan terakhir. Hasil penelitian ini sejalan dengan penelitian yang dilakukan oleh Ehikioya (2018), Rosa (2016), Yuana dkk. (2018), Desmintari dan Yetty (2016), dan Trisnawati (2016) yang menyatakan bahwa profitabilitas berpengaruh negatif terhadap kebijakan hutang.

\subsubsection{Pengaruh Likuiditas terhadap Kebijakan Hutang}

Hasil pengujian menunjukkan bahwa variabel likuiditas yang diproksikan dengan Current Ratio (CR) mempunyai nilai koefisien sebesar -0,143965 dengan nilai signifikansi sebesar 0,0008 . Nilai sign probabilitas dari likuiditas lebih kecil dari 0,01 atau signifikan pada level $1 \%$ maka likuiditas berpengaruh negatif signifikan terhadap kebijakan hutang. Dengan demikian, hipotesis yang telah dirumuskan (H2) diterima. Nilai koefisien likuiditas yang negatif menunjukkan bahwa semakin tinggi likuiditas suatu perusahaan maka akan menurunkan penggunaan hutangnya. Semakin likuid suatu perusahaan berarti perusahaan tersebut mempunyai kemampuan membayar hutang jangka pendek, sehingga cenderung akan menurunkan total hutangnya. Hal ini menunjukkan bahwa perusahaan dengan tingkat likuiditas yang tinggi maka perusahaan tersebut memiliki dana internal yang cukup besar sehingga cenderung tidak memerlukan sumber dana eksternal. Sesuai dengan pecking order theory, dimana perusahaan akan mengutamakan sumber pendanaan internal daripada sumber pendanaan eksternal. Hasil penelitian ini sejalan dengan penelitian yang dilakukan oleh 
Ramadhani dan Barus (2018), Yuana dkk. (2018), Desmintari dan Yetty (2016), Cortez dan Susanto (2012), dan Susanti (2014) yang menyatakan bahwa likuiditas berpengaruh negatif terhadap kebijakan hutang.

\subsubsection{Pengaruh Struktur Aset terhadap Kebijakan Hutang}

Hasil pengujian menunjukkan bahwa variabel struktur aset mempunyai nilai koefisien sebesar $-0,562838$ dengan nilai signifikansi sebesar 0,4073 . Nilai sign probabilitas dari struktur aset lebih besar dari 0,10 atau tidak signifikan pada level 10\% maka struktur aset tidak berpengaruh secara signifikan terhadap kebijakan hutang. Dengan demikian, hipotesis yang telah dirumuskan $(\mathrm{H} 3)$ ditolak. Hasil penelitian ini tidak sesuai dengan teori trade off yang dijelaskan sebelumnya di hipotesis. Hal ini dikarenakan terdapat perusahaan yang memiliki hutang, namun aset tetapnya tidak dijadikan sebagai jaminan. Sehingga besar kecilnya struktur aset tidak mempengaruhi kebijakan hutang perusahaan. Dengan demikian struktur aset tidak berpengaruh terhadap kebijakan hutang perusahaan. Hasil penelitian ini sejalan dengan penelitian yang dilakukan oleh Prayogi dkk. (2016), Desmintari dan Yetty (2016), dan Rifai (2015) yang menyatakan bahwa struktur aset tidak berpengaruh terhadap kebijakan hutang.

\subsubsection{Pengaruh Pertumbuhan Perusahaan terhadap Kebijakan Hutang}

Hasil pengujian menunjukkan bahwa variabel pertumbuhan perusahaan mempunyai nilai koefisien sebesar 0,647567 dengan nilai signifikansi sebesar 0,0000. Nilai sign probabilitas dari pertumbuhan perusahaan lebih kecil dari 0,01 atau signifikan pada level $1 \%$ maka pertumbuhan perusahaan berpengaruh positif signifikan terhadap kebijakan hutang. Dengan demikian, hipotesis yang telah dirumuskan $(\mathrm{H} 4)$ diterima. Nilai koefisien pertumbuhan perusahaan yang positif berarti bahwa semakin tinggi pertumbuhan perusahaan maka akan meningkatkan penggunaan hutang perusahaan. Perusahaan yang sedang tumbuh akan membutuhkan banyak dana yang akan berakibat pada peningkatan hutang. Sesuai dengan pecking order theory, dimana perusahaan akan cenderung mengutamakan pendanaan internal terlebih dahulu, tetapi jika dana internal tidak mencukupi maka dana eksternal yang menjadi alternatif pertama adalah hutang. Hasil penelitian ini sejalan dengan penelitian yang dilakukan oleh Putra dan Ramadhani (2017), Trisnawati (2016), dan Sinaga (2017) yang menyatakan bahwa pertumbuhan perusahaan berpengaruh positif terhadap kebijakan hutang. 


\section{Kesimpulan, Keterbatasan, dan Saran}

\subsection{Kesimpulan}

Penelitian ini bertujuan untuk menguji dan memperoleh bukti empiris tentang pengaruh variabel independen yaitu profitabilitas, likuiditas, struktur aset, dan pertumbuhan perusahaan terhadap variabel dependen yaitu kebijakan hutang. Data sampel yang diperoleh dalam penelitian ini sebanyak 490 sampel dengan perhitungan 98 perusahaan dikalikan selama 5 tahun penelitian. Teknik analisis data dalam penelitian ini menggunakan analisis regresi data panel. Dari hasil uji chow dan uji hausman yang telah dilakukan maka model regresi data panel yang tepat digunakan untuk penelitian ini adalah fixed effect model. Berdasarkan analisis data yang telah dilakukan, hasil penelitian menunjukkan bahwa profitabilitas dan likuiditas berpengaruh negatif terhadap kebijakan hutang. Sedangkan struktur aset tidak berpengaruh terhadap kebijakan hutang, karena terdapat perusahaan yang memiliki hutang namun tidak menjaminkan aset tetap perusahaan tersebut. Sementara itu pertumbuhan perusahaan berpengaruh positif terhadap kebijakan hutang.

\subsection{Keterbatasan}

Berdasarkan hasil penelitian yang dibahas pada bab sebelumnya, maka keterbatasan dalam penelitian ini adalah hanya menggunakan empat variabel independen yaitu profitabilitas, likuiditas, struktur aset, dan pertumbuhan perusahaan.

\subsection{Saran}

Berdasarkan keterbatasan penelitian tersebut, maka untuk penelitian selanjutnya disarankan untuk menambah variabel independen lain yang berkaitan dengan kebijakan hutang seperti free cash flow, ukuran perusahaan, resiko bisnis, kebijakan deviden, pajak, kepemilikan institusional, kepemilikan manajerial.

\section{Daftar Pustaka}

Akoto, R. K., \& Vitor, D. A. (2014). What Determines the Debt Policy of Listed Manufacturing Firm in Ghana? International Business Research, Vol. 7 No. 1.

Andina, Z. (2013). Analisis Pengaruh Profitabilitas, Likuiditas, Pertumbuhan Penjualan, Pertumbuhan Perusahaan, dan Ukuran Perusahaan terhadap Kebijakan Hutang. Skripsi. Universitas Diponegoro.

Brigham \& Houston. (2011). Dasar-Dasar Manajemen Keuangan. Jakarta: Salemba Empat. 
Brigham \& Houston. (2013). Dasar-Dasar Manajemen Keuangan. Jakarta: Salemba Empat.

Chandrasekharan, C. V. (2012). Determinants of Capital Structure in the Nigerian Listed Firms. International Journal of Advanced Research in Management and Social Sciences, Vol. 1 No. 2.

Cortez, M. A., \& Susanto, S. (2012). The Determinants of Corporate Capital Structure: Evidence From Japanese Manufacturing Companies. Journal of International Business Research, Vol. 11 No. 3.

Desmintari \& Yetty, F. (2016). Effect Of Profitability, Liquidity, and Assets Structure on the Company Debt Policy. International Journal Of Business Commerce, Vol. 5 No. 06.

Ehikioya, B. I. (2018). An Empirical Analysis of the Determinants of Corporate Debt Policy of Nigerian Firms. International Journal of Economics and Financial Research, Vol. 4.

Hanafi, M. M., \& Halim, A. (2012). Analisis Laporan Keuangan. Yogyakarta: AMP-YKPN.

Hardiningsih, P., \& Oktaviani, R. M. (2012). Determinan Kebijakan Hutang. Dinamika Akuntansi, Keuangan, dan Perbankan, Vol. 1.

Husnan, S. (2012). Manajemen Keuangan. Yogyakarta: BPFE.

Indraswary, H. U., Raharjo, K., \& Andini, R. (2016). Faktor-Faktor yang Mempengaruhi Kebijakan Hutang pada Perusahaan Property dan Real Estate yang Terdaftar di BEI Tahun 2010-2014. Journal Of Accounting, Vol. 2.

Linda, Lautania, M. F., \& Arfandynata, M. (2017). Determinan Kebijakan Hutang: Bukti Empiris pada Perusahaan yang Terdaftar di BEl. Jurnal Dinamika Akuntansi dan Bisnis, Vol. 4.

Prayogi, D. A., Susetyo, B., \& Subekti. (2016). Pengaruh Struktur Aktiva, Profitabilitas, Pertumbuhan Perusahaan dan Kebijakan Dividen terhadap Kebijakan Hutang. Jurnal Permana, Vol. 7 No. 2.

Primantara, D. Y., \& Dewi, M. R. (2016). Pengaruh Likuiditas, Profitabilitas, Risiko Bisnis, Ukuran Perusahaan, dan Pajak terhadap Struktur Modal. E-Jurnal Manajemen Unud, Vol. 5 No. 5.

Putra, D., \& Ramadhani, L. (2017). Analisis Faktor-Faktor yang Mempengaruhi Kebijakan Hutang pada Perusahaan Jasa Yang Listing di BEI Tahun 2013-2015. Jurnal Akuntansi dan Keuangan, Vol. 8.

Ramadhani, S., \& Barus, A. C. (2018). Kebijakan Hutang pada Perusahaan Sektor Utama yang Terdaftar di Bursa Efek Indonesia Periode 2013-2016. JWEM STIE MIKROSKIL, Vol. 8.

Rifai, M. H. (2015). Pengaruh Risiko Bisnis, Pertumbuhan Perusahaan, Ukuran Perusahaan dan Struktur Aktiva terhadap Kebijakan Hutang pada Perusahaan Sektor Property and Real Estate yang Terdaftar di Bursa Efek Indonesia. Skripsi. Universitas Negeri Yogyakarta.

Rosa, A. M. (2016). Pengaruh Kepemilikan Manajerial, Kebijakan Dividen, Profitabilitas dan Free Cash Flow terhadap Kebijakan Hutang. Artikel IImiah: STIE Perbanas.

Sapitri, E. (2018). Pengaruh Likuiditas dan Profitabilitas terhadap Kebijakan Hutang Perusahaan. Skripsi. Universitas Islam Negeri Raden Intan Lampung.

Sinaga, G. Y. (2017). Pengaruh Pertumbuhan Perusahaan, Free Cash Flow, Struktur Aset, Likuiditas, Profitabilitas, dan Risiko Bisnis terhadap Kebijakan Hutang. Skripsi. Universitas Negeri Semarang.

Surya, D., \& Rahayuningsih, D. A. (2012). Faktor-Faktor yang Mempengaruhi Kebijakan Hutang Perusahaan Non Keuangan yang Terdaftar dalam Bursa Efek Indonesia. Jurnal Bisnis dan Akuntansi, Vol. 14.

Suryani, A. D. (2015). Pengaruh Free Cash Flow, Pertumbuhan Perusahaan, Kebijakan Deviden dan Ukuran Perusahaan terhadap Kebijakan Hutang pada Perusahaan Manufaktur di BEI Tahun 2013. Skripsi. Universitas Negeri Semarang.

Susanti, F. (2014). Pengaruh Likuiditas, Kebijakan Deviden, Struktur Aset, Ukuran Perusahaan dan Pertumbuhan Penjualan terhadap Kebijakan Hutang pada Perusahaan Manufaktur yang Terdaftar di Bursa Efek Indonesia Tahun 2010-2013. Jurnal Akuntansi.

Trisnawati, I. (2016). Faktor-Faktor yang Mempengaruhi Kebijakan Hutang pada Perusahaan Non-Keuangan yang Terdaftar di BEl. Jurnal Bisnis dan Akuntansi, Vol. 18. 
Utami, S. P. S. (2018). Dwi Aneka Jaya Kemasindo dalam pailit punya utang Rp 1,15 triliun, 3 Januari. Diakses pada 23 Agustus 2019. https://nasional.kontan.co.id/news/dajk-dalampailit-punya-utang-rp-115-triliun.

Yeniatie \& Destriana, N. (2010). Faktor-Faktor yang Mempengaruhi Kebijakan Hutang pada Perusahaan NonKeuangan yang Terdaftar di Bursa Efek Indonesia. Jurnal Bisnis dan Akuntansi, Vol. 12.

Yuana, Y. E., Rambe, P. A., \& Ratih, A. E. (2018). Analisis Faktor-Faktor yang Mempengaruhi Kebijakan Hutang pada Perusahaan Manufaktur yang Terdaftar di Bursa Efek Indonesia Periode 2013-2016. Jurnal Universitas Maritim Raja Ali Haji. 